\title{
Specify Mutation Analysis Method
}

National Cancer Institute

\section{Source}

National Cancer Institute. Specify Mutation Analysis Method. NCI Thesaurus. Code C158846.

A request to enter the specific molecular analysis method used to detect and identify mutations in that section of the form. 